\title{
Ignition of cellulose fuel beds by hot metal particles
}

\author{
S. Scott ${ }^{1}$, R. Hadden ${ }^{2}$, A. Yun ${ }^{1}$, C. Lautenberger ${ }^{1}$ \\ \& A. C. Fernandez-Pello \\ ${ }^{I}$ Department of Mechanical Engineering, University of California, \\ Berkeley, USA \\ ${ }^{2}$ BRE Center for Fire Safety Engineering, University of Edinburgh, UK
}

\begin{abstract}
Spotting occurs in wildland fires when fire-lofted embers or hot particles are carried by the wind and fall in areas of unburnt yet flammable vegetation leading to ignition of new, discrete fires. Significant work has been conducted on predicting the trajectories of the embers but little fundamental work is available related to the capability of these embers or particles to ignite vegetation. This paper consists of an experimental and theoretical study of ignition of fuel beds by hot metal particles. Both laboratory and real life fuel beds have been tested. Spherical steel particles with diameters in the range 0.8 to $19.1 \mathrm{~mm}$ heated to temperatures between 500 and $1300^{\circ} \mathrm{C}$ are used in the experiments. A relationship between the size of the particle and temperature required for flaming or smoldering ignition is found in powdered cellulose. These results are used to assess a model based on Hot Spot Ignition Theory to determine the particle sizetemperature relationship required for ignition of a cellulose fuel bed. The model qualitatively predicts the ignition response of the fuel to a given particle size and temperature. Similar experiments were also conducted using pine needles as the fuel bed.
\end{abstract}

Keywords: ignition by hot particles, fire spotting.

\section{Introduction}

Under dry, hot, and windy conditions devastating wildland and wildland urban interface (WUI) fires can be spread by spotting. Spotting leads to more rapid fire spread than flame front propagation because embers generated by burning 
vegetation or structures are lofted by fire plumes and transported downwind to ignite secondary fires or structures remote from the fire front. Spotting fires are especially dangerous on the WUI because this mode of fire spread can surround firefighters as they attempt to fight the fire and civilians and they try to evacuate the area. Many structures destroyed during WUI fires are not ignited by direct flame impingement, but rather by embers penetrating vents/eaves or direct ignition of roof construction and other "soft" targets. Following the devastating 1994 Sydney wildland fires, a statistical study determined that $75 \%$ of houses were ignited by firebrands, while $25 \%$ were ignited by firebrands and flame radiation (Ramsey and MacArthur [1]). A typical example showing ignition of houses by embers, from the Witch Creek Fire in San Diego, California, is shown in Figure 1 (www.sandiegonewsphotographer.com [2]). Two houses are completely destroyed while the surrounding vegetation is unburned and several surrounding houses remain intact. Molten or burning particles can also be generated by high-voltage powerline conductors clashing in high winds. When these hot particles (typically copper or aluminum) reach the ground they may ignite fires in surrounding dry vegetation.

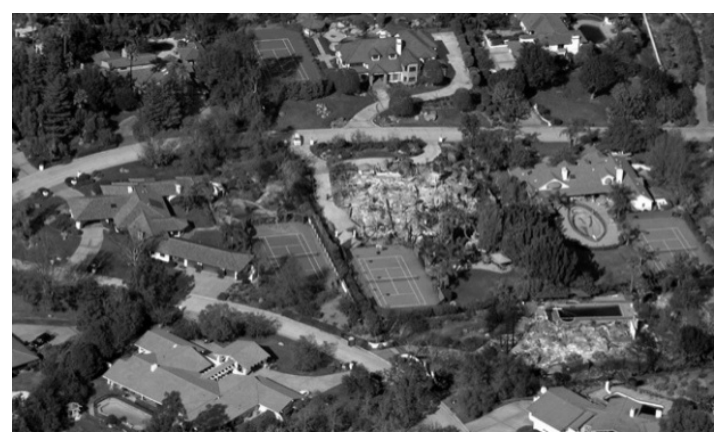

Figure 1: Aerial photograph taken following the 2007 Witch Creek Fire (www.sandiegonewsphotographer.com [2]). Vegetation unburned, but two houses are completely destroyed while surrounding houses remain intact, suggesting ignition by lofted embers or firebrands.

The ability to accurately predict whether an ember or heated particle having certain characteristics represents a competent ignition source for a given fuel bed has not been thoroughly investigated. Only a few studies have examined the critical conditions that can lead to fire initiation after the landing of a firebrand or particle on a particular fuel bed. These studies are primarily experimental in nature (Stokes [3], Rowntree and Stokes [4], Manzello et al. [5-5], Pitts [6]) and no comprehensive theoretical studies have yet been conducted to analyze the problem, or develop generalized predictive tools. Consequently, current models of wildland fire propagation (Finney [7], Linn et al. [8], Mell et al. [9]) lack capabilities for accurately predicting the initiation of spot fires.

The work presented here is a step toward developing the knowledge needed to accurately predict the conditions leading to ignition of fuel beds by embers and 
heated particles. Inert steel spheres are used to approximate firebrands/heated particles as this removes uncertainty introduced by the burning ember (ember temperature, char layer thickness, combustion characteristics, thermal properties, etc.). Similarly, powdered cellulose is used as the target fuel because it is homogeneous in composition and has known properties. Additionally, a simplified analytical treatment based on the classical hot spot theory is reviewed and its predictive capabilities are assessed. Finally, to test a 'real world' fuel, a fuel bed of pine needles in order to determine a minimum particle diameter for ignition.

\section{Background}

\subsection{Firebrand/particle generation and transport}

Firebrand generation is the process through which natural fuels broken into smaller burning pieces during a fire and lofted by a buoyant fire-induced plume or powerlines interact generating molten metal particles. Yoshioka et al. [10] and Manzello et al. [5, 11] have characterized the number and size distribution of brands generated by different fuels. Firebrands generated by a single Douglas fir can range in size from $200 \mathrm{~mm}$ to around $10 \mathrm{~mm}$ in diameter.

The trajectories and burning rates of firebrands or heated particles lofted by fires have been studied more extensively (Tarifa et al. [14], Koo et al. [23]. Collectively, the above studies show that small embers or particles are easily lofted and can travel long distances. However, they may burn out or have a low temperature at landing. In comparison, large embers or particles may have long burn times, but they are more difficult to transport and therefore do not travel far from the fire front. Embers or particles of intermediate size have a relatively long burn time and can be lofted considerable distances.

\subsection{Spot fire formation}

The aspect of spot fire formation that is least understood is what happens after a firebrand or heated particle lands on a target fuel bed. Of greatest interest is whether or not ignition occurs. This complex process depends on several factors, including the size and state of the brand (temperature, smoldering/glowing, flaming), the characteristics of the fuel bed on which it lands (temperature, density, porosity, moisture content), and environmental conditions (temperature, humidity, wind velocity). Ignition of fuel beds by fire brands and heated surfaces has been studied primarily experimentally, in particular by workers at NIST [4-7]. Studies on the ignition by metal particles have been reported by Rowntree and Stokes [3, 4].

Using single glowing embers of Douglas Fir $(5$ or $10 \mathrm{~mm}$ diameter, 51 and $76 \mathrm{~mm}$ length respectively) under air flow of 0.5 or $1 \mathrm{~m} / \mathrm{s}$, Manzello et al. [5] found that smoldering ignition would occur in shredded paper but no ignition would occur in pine needles or hardwoods. For flaming embers under the same conditions, flaming ignition would occur in all fuels except hardwood mulch at 
$11 \%$ moisture content. Similar results are found using disk shaped embers Manzello et al. [5, 6] where flaming ignition occurred only when flaming embers are dropped.

A few theoretical studies related to ignition of fuel beds by have been conducted, but these models remain largely unvalidated. In particular, "hot spot" theories as originally developed in the 1960s and 1970s (Gol'dshleger et al. [24], Thomas [28] and applied later Jones [29-31] to natural fuels seem to be the most promising simple approach. More recently, detailed numerical models have been applied to simulate spot fire initiation (Zvyagils'kaya and Subbotin [32], Lautenberger and Fernandez-Pello [34].

Babrauskas [33] discusses the possibility of using energy as a criterion for ignition and concludes that it is not sufficient as particles of different size with the same energy do not necessarily result in ignition. He also notes that laboratory studies to date do not allow the determination of which thermal properties dictate incendivity. Babrauskas concludes that a "hot spot" ignition theory will allow reasonable prediction of particle size-temperature relationships for ignition.

\section{Experiment description}

The experimental apparatus used in this work is shown in Figure 2. The fuel bed is mounted in the bottom of a wind tunnel with the sample surface flush with bottom of the tunnel. The wind-tunnel is $550 \mathrm{~mm}$ in length with a $130 \mathrm{~mm}$ by $80 \mathrm{~mm}$ cross section. The sample holder is $150 \mathrm{~mm}$ long, $100 \mathrm{~mm}$ wide and 50 $\mathrm{mm}$ deep and its leading edge is $150 \mathrm{~mm}$ from the inlet of the tunnel. The fuel was dry powdered $\alpha$-cellulose (bulk density of approximately $200 \mathrm{~kg} \cdot \mathrm{m}^{3}$ ). The mass and volume of the cellulose remained constant throughout the tests. A similar procedure was used to condition the pine needles fuel bed. Compressed air flows through the tunnel at a velocity of $0.5 \mathrm{~m} / \mathrm{s}$. Sheathed K-type thermocouples are placed in the fuel sample at locations shown in Figure 3. The thermocouples are used to follow the progress of the smolder or flame front

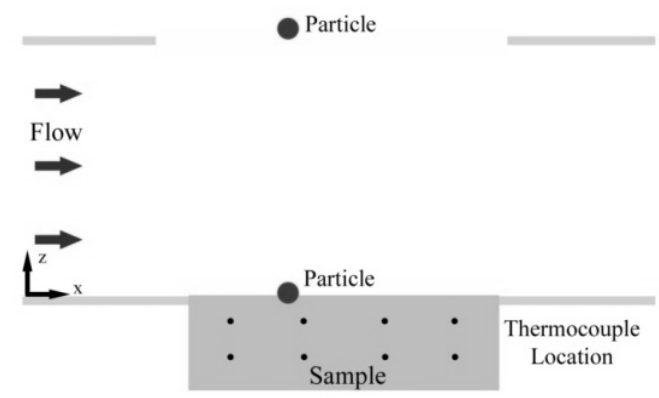

Figure 2: $\quad$ Simplified schematic. 


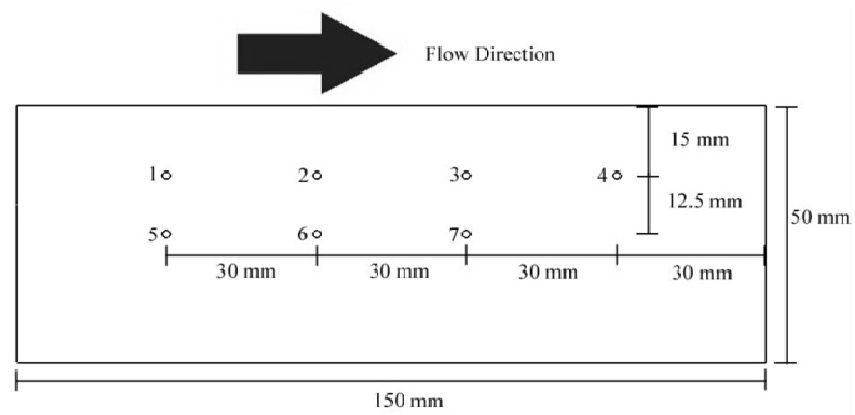

Figure 3: $\quad$ Fuel bed dimensions and thermocouple locations.

through the fuel bed. Spherical steel particles with a diameter between 0.8 and $19.1 \mathrm{~mm}$ heated to temperatures between 500 and $1300^{\circ} \mathrm{C}$ were used to simulate the embers or heated particles.

During an experiment, a steel particle of desired size is heated with a propane or propylene torch. Once the particle has reached the desired temperature it is dropped onto the sample surface from a height of approximately $20 \mathrm{~mm}$. The particle is dropped approximately $35 \mathrm{~mm}$ from the leading edge of the sample. Fuel bed temperature is recorded along the centerline at seven locations as shown in Figure 3.

\section{Experimental results}

\subsection{Powdered cellulose results}

Experiments are undertaken to identify the relationship between hot particle size and temperature and the ignition in a sample of cellulose. The powdered cellulose was observed to undergo both flaming and smoldering ignition depending on the particle characteristics. In flaming ignition the flame would be initiated around the hot particle and if the particle was hot enough, flames would propagate across the free surface of the fuel sample then extinguish as they reach the sample's end. In depth smoldering would then be seen to continue for several hours.

In the case of smoldering ignition, a smolder front would be established around the hot particle. This would then propagate laterally as well as in depth. In all cases when smoldering was ignited, the sample was seen to burn to completion. Transition from smoldering to flaming was not observed.

\subsubsection{Temperature profiles}

Figure 4 shows the temperature profile for a sample in which flaming occurred initially across the surface of the sample followed by in depth smoldering. Peak fuel bed temperatures are in the range $465^{\circ} \mathrm{C}$ to $550^{\circ} \mathrm{C}$. Temperatures in depth were higher than those closer to the free surface due to reduced heat losses. The 


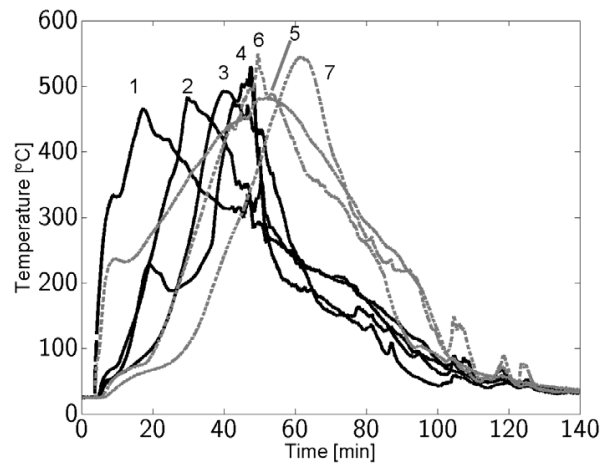

Figure 4: Temperature profiles in the fuel bed for a sample in which flaming was observed. Thermocouple locations refer to those in Figure 3.

temperature peak in the solid phase advances both laterally and in depth from the point where the hot particle was dropped.

\subsubsection{Smolder spread rate}

The smolder spread rate was found to be a function of depth and distance from the hot particle. Spread rate was calculated by finding the times each thermocouple reached $300^{\circ} \mathrm{C}$ and dividing the distance between the thermocouples by the time between adjacent thermocouples reaching this temperature.

For the example above, at a depth of $15 \mathrm{~mm}$ below the free surface, spread rates were $2.0,3.1$ and $5.3 \mathrm{~mm} / \mathrm{min}$ at positions between 30 and 60,60 and 90 and 90 and $120 \mathrm{~mm}$ from the leading edge respectively. This suggests that as the size of the reaction front grows, the spread rate increases. However, at a depth of $17.5 \mathrm{~mm}$ below the free surface, this effect is much reduced and the spread rates are 2.9 and $2.7 \mathrm{~mm} / \mathrm{min}$ at between thermocouple locations 30 and $60 \mathrm{~mm}$ and 60 and $90 \mathrm{~mm}$ from the leading edge respectively. These spread rates are in agreement with others reported in the literature (Rein [36]).

\subsubsection{Propensity for ignition}

Figure 5 shows the ignition propensity as a function of particle size and temperature. Triangles represent direct flaming ignition, squares are smoldering ignition, and asterisks represent no ignition. The data clearly show a demarcation between no ignition, smoldering ignition and flaming ignition and that both for flaming and smolder ignition smaller particles require higher temperatures than larger particles. Due to the experimental method for delivering the hot particles, it was not always possible to ensure the particles were exactly the same temperature upon landing on the fuel and obtained the same level of submergence in the cellulose. The result is that there is some overlap between the ignition types in some cases

For the range of particles tested, the minimum particle temperature at which smoldering could be ignited was $550^{\circ} \mathrm{C}$ and the minimum temperature at 


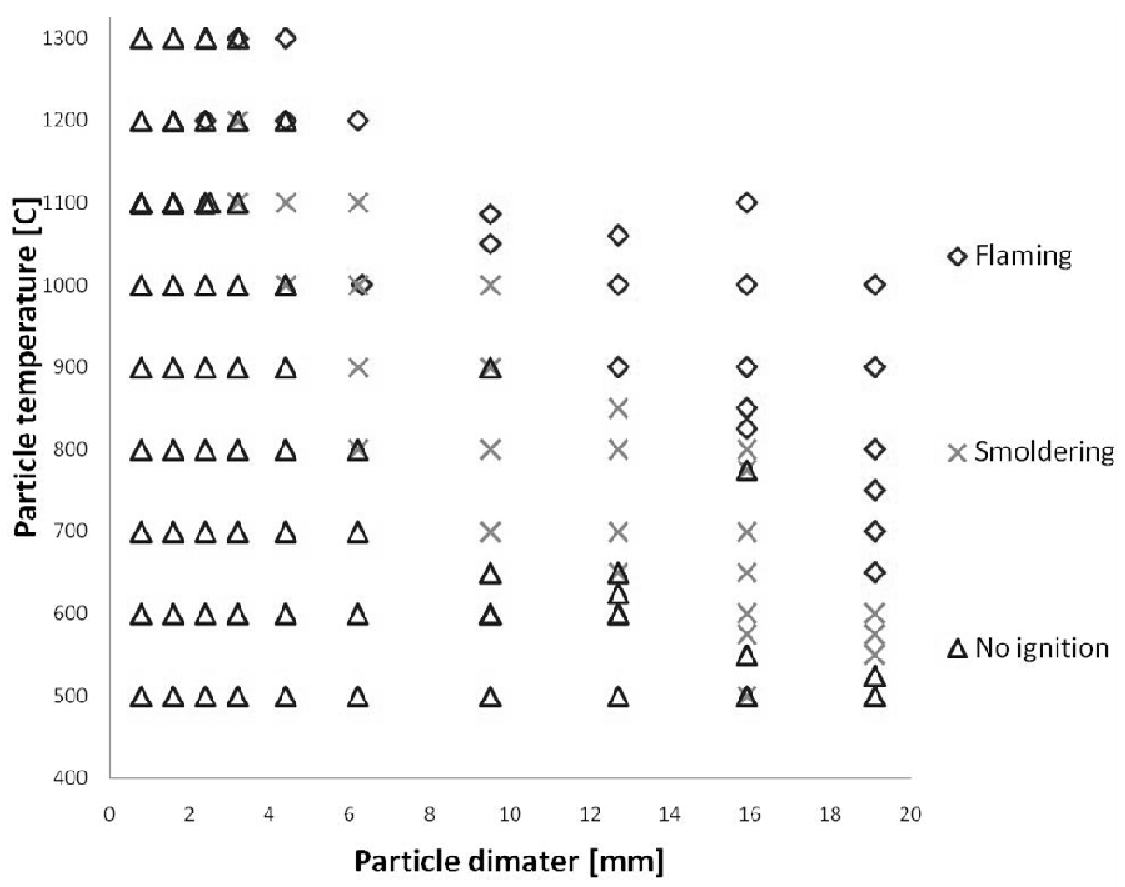

Figure 5: $\quad$ Ignition propensity of dry cellulose using heated steel spheres.

which flaming ignition occurred was $650^{\circ} \mathrm{C}$. In both cases, this was for a particle diameter of $19.1 \mathrm{~mm}$. Flaming was observed for particles larger than $2.4 \mathrm{~mm}$ heated to at least $1200^{\circ} \mathrm{C}$.

\subsubsection{Hot spot theory}

It has been suggested that hot spot theory (Gol'dshleger et al. [24], Thomas [28]) can be used to model the ignition of natural fuels by heated particles. For example, in a sequence of three papers, Jones [29-31] applied hot spot theory to simulate the ignition of forest litter by copper particles. In Jones [29], the theory of Gol'dshleger et al. [22] is applied. This same theory (Gol'dshleger et al. [24]) has been recommended by Bowes [35] for its compromise between accuracy and tractability, and has also been applied by Babrauskas [33] to model the barley grass ignition experiments of Rowntree and Stokes [4] involving heated particles. Since the hot spot theory of Gol'dshleger et al. [22] seems a logical starting point for modeling the present experiments, it is developed in detail in Hadden et al. [38] then applied to correlate the present experiments. The governing equation for hot spot theory is show in eqn (1).

$$
r_{c r}=\delta_{c r} \sqrt{\frac{k}{\rho A \Delta H} \frac{R T_{p 0}^{2}}{E} \exp \left(\frac{E}{R T_{p_{0}}}\right)}
$$


The constants in eqn (1) can be determined experimentally. By creating two constants, $\mathrm{C}_{1}$ and $\mathrm{C}_{2}$, defined as follows:

$$
\begin{gathered}
C_{1}=\delta_{c r} \sqrt{\frac{k}{\rho A \Delta H} \frac{R T_{p 0}^{2}}{E}} \\
C_{2}=\frac{E}{R}
\end{gathered}
$$

by making these substitutions eqn (1) becomes the following:

$$
2 r_{p}=C_{1} T_{p} \sqrt{\left(\exp \left(\frac{C_{2}}{T_{p}}\right)\right)}
$$

The regions of flaming, smoldering and no ignition can be demarcated by using a curve fit to find $\mathrm{C}_{1}$ and $\mathrm{C}_{2}$. The values of $\mathrm{C}_{1}$ and $\mathrm{C}_{2}$ for smoldering and flaming ignition are given in Table 1.

Table 1: Values of constants for demarcation of ignition regimes.

\begin{tabular}{|c|c|c|}
\hline & $\mathrm{C}_{1}$ & $\mathrm{C}_{2}$ \\
\hline Smoldering & 0.00034 & 4912 \\
\hline Flaming & 0.00054 & 5452 \\
\hline
\end{tabular}

The results of Figure 6 agree qualitatively with those of Stokes and Rowntree $[3,4]$. An interesting feature of Figure 6 is the narrowing of the smolder region, suggesting that particles above a certain longer cause smoldering ignition to occur in the fuel. Further testing is required to identify the exact temperature at which this occurs.

\subsection{Pine needles results}

Ember ignition of pine needles has been studied as a function of the size of the hot particles. Particles of sizes 18, 15, 12, 10, 7 and $5 \mathrm{~mm}$ have been studied. In all cases, particles were heated to approximately $1100^{\circ} \mathrm{C}$ using a propane torch. A wind speed of $0.54 \mathrm{~m} / \mathrm{s}$ was used. The bulk density of the pine needle bed was $25 \mathrm{~kg} / \mathrm{m}^{3}$.

In order to determine the risk associated with embers of various sizes, a criterion needs to be chosen to determine the extent of combustion. In this work, mass loss is used. Figure 7 shows mass loss as a function of ember size. Unsustained smolder results in localized mass loss in the region of the ember around $2-5 \%$. If the sample transitions to flaming or flames from the outset then mass loss is high $85-91 \%$. No samples were observed to smolder to any great extent without the transition to flaming occurring. It is seen that for the present tests the minimum particle size for flaming ignition is around $8 \mathrm{~mm}$. 


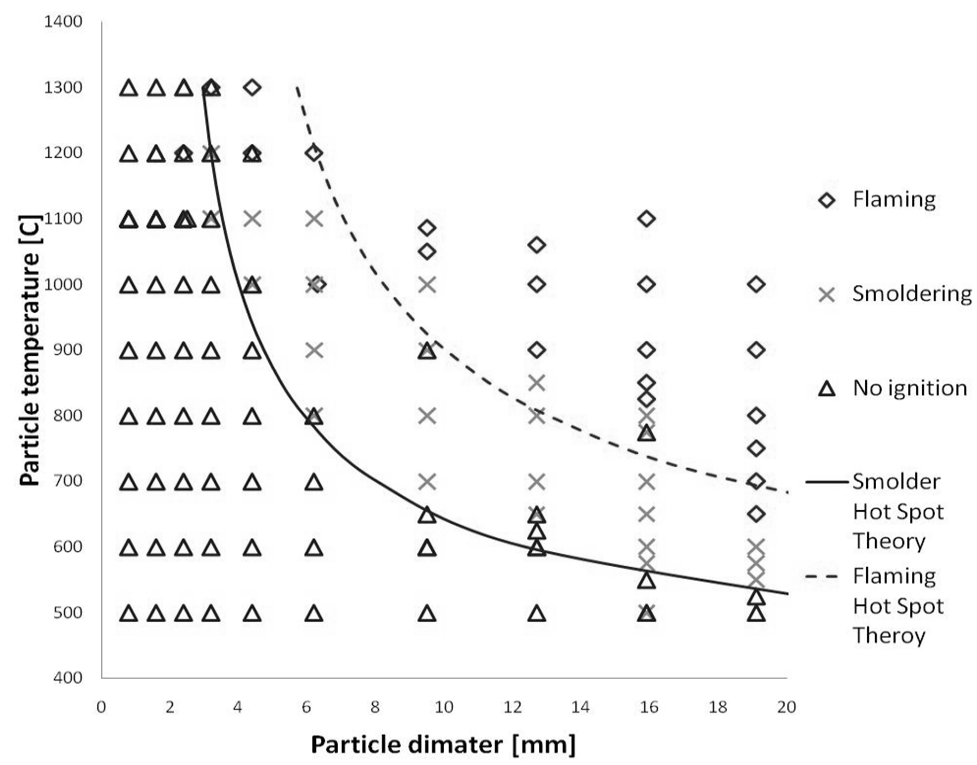

Figure 6: Ignition propensity of dry cellulose using heated steel spheres correlated using hot spot theory.

Figure 7 also highlights one of the difficulties with the experiments using real fuels: ensuring consistency in ember position and depth in the fuel sample. This depends on the structure of the fuel bed as the pine needles are inhomogeneous. This can result in samples not igniting consistently such as those using a $15 \mathrm{~mm}$ particle in Figure 7. This means that a probabilistic approach is required to study the problem and good characterization of the fuel bed is important.

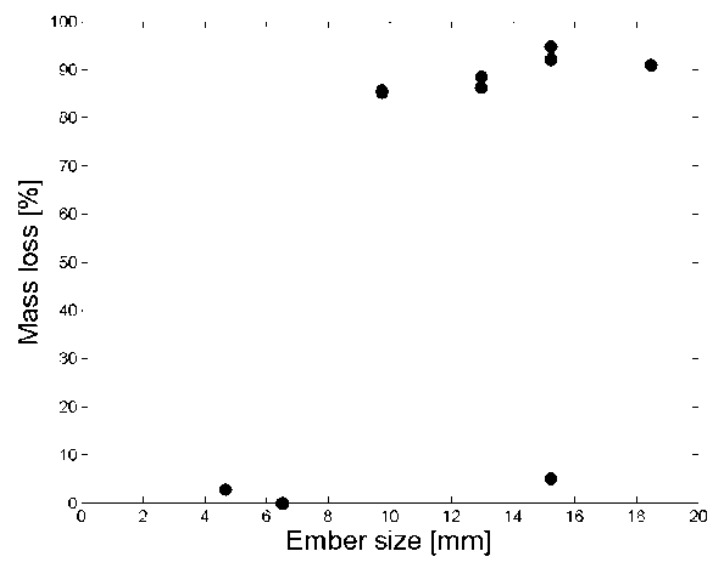

Figure 7: Mass loss of sample as a function of particle size. Wind speed was constant at $0.5 \mathrm{~m} / \mathrm{s}$. 


\section{Concluding remarks}

Ignition of cellulose fuel beds by hot spherical particles has been studied experimentally and a model of hot spot ignition presented. The results show as particle size is reduced; increased temperature is required for ignition. For a particle size of $2.4 \mathrm{~mm}$, temperatures of $1200^{\circ} \mathrm{C}$ were required for flaming ignition and this was reduced to $650^{\circ} \mathrm{C}$ for particles of $19.1 \mathrm{~mm}$. This suggests that the ignition propensity is a function of both particle size and particle temperature. Additionally, hot spot ignition theory seems to provide qualitative agreement with experimental results and with continued development may allow good correlation.

Experiments using a real fuel to determine the likelihood of ignition of a bed of pine needles as a function of hot particle size have been undertaken. It is suggested that there is a minimum particle size of $8 \mathrm{~mm}$ in order for the pine needles to transition to flaming. Due to the inhomogenous nature of pine needles, the ability to predict the behavior of such fuels is vital in improving wild fire spread models and results will be used to improve and validate the model using such materials. In the future, more experiments involving variations in windspeed, particle/ember type, and fuel bed type will help in the creation of a model to improve prediction and encapsulate the transition to flame. This will be an aid in the creation of fire danger maps on the urban/wildland interface.

\section{References}

[1] Ramsey, G.C. and McArthur, N.A., "Building in the Urban Interface: Lessons from the January 1994 Sydney Bushfires," Bushfires 1995, Hobart, Tasmania, 1995.

[2] http://www.sandiegonewsphotographer.com/Firestorm07Web/

Escondido_aerial_Joe_Klein/album/slides/WITCH-FIRE35.html (retrieved on August $15,20 \overline{0} 9$ )

[3] Stokes, A.D., "Fire Ignition by Copper Particles of Controlled Size," Journal of Electrical and Electronics Engineering, Australia 10: 188-194 (1990).

[4] Rowntree, G.W.G. and Stokes, A.D., "Fire Ignition by Aluminum Particles of Controlled Size," Journal of Electrical and Electronics Engineering, Australia 14: 117-123 (1994).

[5] Manzello, S.L., Cleary, T.G., Shields, J.R., and Yang, J.C., "On the ignition of fuel beds by firebrands," Fire and Materials 30: 77-87 (2006).

[6] Manzello, S.L., Cleary, T.G., Shields, J.R., and Yang, J.C., "Ignition of mulch and grasses by firebrands in wildland-urban interface fires," International Journal of Wildland Fire 15: 427-431 (2006).

[7] Manzello, S.L., Cleary, T.G., Shields, J.R., Maranghides, A., Mell, W., and Yang, J.C., "Experimental Investigation of Firebrands: Generation and Ignition of Fuel Beds," Fire Safety Journal 43: 226-233 (2008).

[8] Pitts, W., "Ignition of Cellulosic Fuels by Heated and Radiative Surfaces," NIST Technical Note 1481, March 2007. 
[9] Finney, M.A., "FARSITE: Fire Area Simulator-model development and evaluation," US Department of Agriculture, Forest Service, Rocky Mountain Research Station, Research Paper RMRS-RP-4, Ogden, UT, 1998.

[10] Linn, R., Resiner, J., Colman, J.J., and Winterkamp, J., "Studying wildfire behavior using FIRETEC," International Journal of Wildland Fire 11: 233 - 246 (2002).

[11] Mell, W., Jenkins, M.A., Gould, J., Cheney, C., “A physics-based approach to modeling grassland fires," International Journal of Wildland Fire 16: 122 (2007).

[12] Yoshioka, H., Hayashi, Y., Masuda, H., and Noguchi, T., "Real-Scale Fire Wind Tunnel Experiment on Generation of Firebrands from a House on Fire," Fire Science and Technology 23: 142-150 (2004).

[13] Manzello, S.L., Shields, J.R., Cleary, T.G., Maranghides, A., Mell, W.E., Yang, J.C., Hayashi, Y., Nii, D., and Kurita, T., "On the development and characterization of a firebrand generator," to appear in Fire Safety Journal (2008).

[14] Tarifa, C.S., del Notario, P.P., and Moreno, F.G., "On the Flight Paths and Lifetimes of Burning Particles of Wood," Proceedings of the Combustion Institute 10: 1021-1037 (1965).

[15] Lee, S.L., and Hellman, J.M., "Firebrand Trajectory Study Using an Empirical Velocity-Dependent Burning Law," Combustion and Flame 15: 265-274 (1970).

[16] Albini, F.A., "Spot Fire Distance from Burning Trees: a Predictive Model," GTR-INT-56, USDA Forest Service (1979).

[17] Albini, F.A., "Potential Spotting Distance from Wind-Driven Surface Fires," USDA Forest Service Research Paper ZNT-309 (1983).

[18] Tse, S.D. and Fernandez-Pello, A.C., "On the flight paths of metal particles and embers generated by power lines in high winds - a potential source of wildland fires," Fire Safety Journal 30: 333-356 (1998).

[19] Woycheese, J.P., "Wooden disk combustion for spot fire spread," Interflam 2001 pp. 101-112 (2001).

[20] Himoto, K. and Tanaka, T. "Transport of Disk-Shaped Firebrands in a Turbulent Boundary Layer," Fire Safety Science-Proceedings of the 8th International Symposium, pp. 433-444 (2005).

[21] Anthenien, R.A, Tse, S.D., and Fernandez-Pello, A.C., "On the trajectories of embers initially elevated or lofted by small scale ground fire plumes in high winds," Fire Safety Journal 41: 349-363 (2006).

[22] Sardoy, N., Consalvi, J.-L., Poterie, B., Loraud, J.-C., and Fernandez-Pello, C., "Modeling Transport and Combustion of Firebrands from Burning Trees," Combustion and Flame 150: 151-169 (2007).

[23] Koo, E., Pagni, P., and Linn, R., "Using FIRETEC to Describe Firebrand Behavior in Wildfires," Fire and Materials 2007, San Francisco, CA (2007). 
[24] Gol'dshleger, U.I., Pribytkova, K.V., and Barzykin, V.V., "Ignition of a Condensed Explosive by a Hot Object of Finite Dimensions," Fizika Goreniya I Vzryva 9: 119-123 (1973).

[25] Zinn, J., "Initiation of Explosions by Hot Spot," Journal of Chemical Physics 36: 7 (1949).

[26] Boddington, T., "The growth and decay of hot spots and the relation between structure and stability," Proceedings of the Combustion Institute 9: 287-293 (1963).

[27] Friedman, M.H., "A Correlation of Impact Sensitivities by Means of the Hot Spot Model," Proceedings of the Combustion Institute 9: 294-302 (1963).

[28] Thomas, P.H., "A Comparison of Some Hot Spot Theories," Proceedings of the Combustion Institute 10: 369-372 (1965).

[29] Jones, J.C., "Predictive Calculations of the Effect of an Accidental Heat Source on a Bed of Forest Litter," Journal of Fire Sciences 11: 80-86 (1993).

[30] Jones, J.C., "Further Calculations Concerning the Accidental Supply of Heat to a Bed of Forest Material," Journal of Fire Sciences 12: 502-505 (1994).

[31] Jones, J.C., "Improved Calculations Concerning the Ignition of Forest Litter by Hot Particle Ingress," Journal of Fire Sciences 13: 350-356 (1995).

[32] Zvyagils'kaya, A.I. and Subbotin, A.N., "Influence of Moisture Content and Heat and Mass Exchange with the Surrounding Medium on the Critical Conditions of Initiation of Surface Fire," Combustion, Explosions, and Shock Waves 32: 558-564 (1996).

[33] Grishin, A.M., Dolgov, A.A., Zima, V.P., Kryuchkov, D.A., Reino, V.V., Subbottan, A.N., and Tsvyk, R.S., "Ignition of a Layer of Combustible Forest Materials," Combustion, Explosions, and Shock Waves 34: 613-620 (1998).

[34] Lautenberger, C., and Fernandez-Pello, A.C., "Modeling Ignition of Combustible Fuel Beds by Embers and Heated Particles," Forest Fires 2008.

[35] Babrauskas, V., Ignition Handbook: Principles and Applications to Fire Safety Engineering, Fire Investigation, Risk Management, and Forensic Science, Fire Science Publishers, Issaquah, WA, 2003, pp. 843.

[36] Rein, G., "Smoldering combustion phenomena in science and technology," International Review of Chemical Engineering 1: 3-18 (2009).

[37] Bowes, P.C., Self Heating: Evaluating and Controlling the Hazards, Elsevier, 1984.

[38] Hadden, R., Scott, S., Lautenberger, C., Fernandez-Pello, A.C., "Ignition of Combustible Fuel Beds by Embers and Heated Particles," Western States Section Spring Meeting, The Combustion Institute, Boulder, Colorado. March 2010. 